\title{
editorial
}

\section{Islam and gender in Europe: subjectivities, politics and piety}

'Is Islam reconcilable with feminism?' asks Haideh Moghissi (1999), echoing a concern that is currently dramatized in numerous ways across and beyond Europe. The growing presence and visibility of Muslims in European liberal democracies and the post-9/11 'war on terror' context has given urgency to debates on the contradictions, struggles but also reconciliations between feminism and Muslim religious practices and forms of religious life. This special issue does not seek to answer the question whether Islam is reconcilable with feminism, but rather its aim is to unpack the theoretical, analytical and ethnographic interface of the complex and internally heterogeneous traditions that we identify as 'feminist' and 'Islamic'.

A number of questions relating to subjectivities, politics and piety are entangled in current debates on Islam and gender in Europe. This special issue investigates these questions both through ethnographic accounts of how the relationship between feminism and Islam is played out in various contemporary settings and through discussions of how this relationship articulates at the level of theory and epistemology. While limiting ourselves to the regional setting of 'Europe', where these questions have become salient, we pursue the lines traced by post-colonial and post-structuralist enquiries into the complex dynamics and relationships between various forms and notions of feminism and various forms and notions of Muslim gender conceptions. This issue furthers the available scholarship on two levels: on the one hand, the contributors trace discourses and sexual politics on Muslim gender norms within European liberal-secular settings. On the other hand, by bringing this into conversion with ethnographic accounts, we look at the 'effects' that these liberal-secular settings potentially have on committed pious Muslim subjects.

One set of questions concerns convergences and differences in Muslim women's experiences and subject formations. The authors of this special issue explore possible subject positions that are available to minoritized Muslim women in Europe and ask how these positionings relate to different 'feminisms' and questions of gender justice. They explore a wide spectrum of positions, including Muslim women's cultivation of pious sensibilities within liberal-secular European societies, as well as the cultivation of 'secular' 
sensibilities. The issue also focuses on the subject positions adopted by feminists (and others) in relation to Islam. It asks how these positions are shaped by the current construction (by media and governments) of Islam as the 'other' of 'the West' and by the regulation of gendered Muslim subjects through various means.

On the theoretical and epistemological level, the issue addresses the question of whether, and to what extent, existing tools in gender studies and feminist theory allow us to grasp the complexities of Islamic gendered practices and politics. Central in engaging this question is examining the ways in which such practices and politics challenge key assumptions within gender studies and feminist theory. Scrutinizing current debates on Islam and gender in Europe also produces insights into the broader sociocultural processes through which the relationship between religion and secularism, the private and the public, minority and majority, is currently being re-configured.

One key theoretical background for current discussions on gendered Islam in Europe is the rhetorical question, raised in Susan Moller Okin's (1999) essay 'Is multiculturalism bad for women?'. By expressing concern for the oppressive and patriarchal character of a commitment to monotheist religions (in particular Islam), Okin and others demarcated an important tension between liberal feminist assumptions and the political recognition of cultural or religious particularities in multicultural settings. However, Okin's essay simultaneously reveals some of the major shortcomings and ambivalences of liberal theory and practice.

As many critics of Okin's theses have pointed out (Al-Hibri, 1999; Honig, 1999; Gressgård and Jacobsen, 2003; Phillips, 2007), her assumptions about the patriarchal structures of 'traditional cultures' rest on an essentialist understanding of culture in general and of Muslim cultures in particular. Moreover, her alarmed care for the well-being of women from 'minority cultures' reveals a symptomatic blindness towards Okin's own liberal bias, which figures as the unmarked backdrop for evaluating the level of freedom or unfreedom of 'other cultures'. As critics of political liberalism have recurrently pointed out, while being anchored in the ideal of leaving individuals the freedom to choose, liberal thought has always entailed the risk of operating with a normative notion of freedom, to which individuals had to confine, in order 'to understand and enact their lives in terms of choice' (Rose, 1999: 87).

The rhetorical question raised by Abu-Lughod (2002), on whether Muslim women really needed saving, precisely hints to the ambivalent effects entailed in all efforts to implement and institutionalize one single mode of freedom, regardless of contextual and cultural particularities. This is obvious not least in post-9/11 efforts to reshape Muslim subjectivities and sensibilities, whether by military, political or civic means, and the concurrent production of Muslims as 'others' 
within the nation-state and as civilizational 'others' of the West (see Hirschkind and Mahmood, 2002; Brown, 2006; Mahmood, 2009).

While the civilizational discourse frames part of the political and academic discourse on Islam and gender alike, an increasing number of scholars also address the complexity of Muslim gender norms and highlight the difficulty to simply juxtapose them to liberal and egalitarian gender regimes (Abu-Lughod, 1986; Ahmed, 1992; Göle, 1996; Deeb, 2006). The emergence of 'Islamic Feminism' (Barlas, 2002; Wadud, 2006; Badran, 2007) is probably the most obvious example illuminating the various ways in which gender justice can be legitimized and furthered on the basis of Islamic traditions. Muslim women's engagement in Islamic revivalist movements, and pursuit of piety within them, has also been analysed in terms of 'bargaining with patriarchy' or furthering gender justice and women's autonomy within a religious framework. Yet, as Saba Mahmood (2005) in her groundbreaking work 'Politics of Piety' reminds us, the scholarly accounts of these trends within Islamic movements tend to repeat some of the basic assumptions of liberal feminism by conceptualizing and praising the agency of committed Muslim women in terms of individual autonomy and resistance. Mahmood's work, in particular, has encouraged scholars to consider how we are to understand and conceptualize discourses and practices with a non-liberal impetus without either identifying them as deviating from or gradually adjusting to the liberal norm. In this light, the question of whether feminism and Islam are reconcilable turns out to be a 'false' question, or at least one that potentially prevents us from addressing other crucial questions, such as the ethical components of male and female subject formation within Islamist movements, interrelations between constructions of feminism and constructions of otherness and their effects on processes of Muslim subject formation or alliances of political discourse and polemics on Muslim gender regimes and feminist scholarship. This special issue should be understood as a contribution to this effort to reorganize and reframe our questions with regard to the complexity of both feminisms and Muslim gender norms, practices and conceptions.

The articles of this special issue should be read in light of their location within the current climate in Europe, in which the condemnation of multiculturalism has almost become consensual, thus giving the academic discussion triggered by Okin's assumptions new relevance and a new character. Recent discussions on Muslim's need to 'integrate' into European liberal-secular orders show the extent to which these arguments have entered the political landscape and are transformed into a populist discourse. Throughout the last decade, this discussion has increasingly been centred on Muslim norms and practices generally and Muslim gender norms in particular. This is attested to by a large number of controversies running through the continent on bodily practices like veiling, arranged/forced marriages or polygamy. Here, legitimate concerns about practices that cause harm to women are frequently 'racialized'. Anti-Muslim 
sentiment seems increasingly to become a normalized part of the very fabric of society and is increasingly subsumed and hidden behind a concern for women and, more recently, also for LBGTs (Lesbian Bisexual Gay and Transgender).

As the contributions by Sarah Bracke and Schirin Amir-Moazami in this issue show, emerging sexual politics take on specific national shapes. However, they also share some common characteristics, most notably expressed in the 'civilizational paradigm' that underpins their discursive structures. Bracke's article demonstrates how the intersection between Islam and sexual politics is played out in the Dutch context and traces its path into a hegemonic civilizational discourse. Meanwhile, Amir-Moazami's article demonstrates how this discourse and its particular 'German touch' has currently taken concrete forms of political action with different, yet complementary rationalities. Amir-Moazami analyses this as expressions of 'governmentalizing' gendered Islam and looks at its forms of subject production, via a rhetoric that simultaneously endorses Muslims while aiming to transform Muslim gender norms according to a particular liberal-secular script.

Although there is clearly no linear causality between the various technologies of power at stake here, and the forms of Muslims subjectivities that we as researchers can observe, we can assume that the technologies operating in the processes of 'governmentalizing' Islam in Europe are inscribed in those very subjects who are targeted through it. Tracing and juxtaposing different cases of such processes can help us to show that these inscriptions take on multiple, contradictory and probably also dynamic forms. Bracke's article addresses this interrelation between power and subject formation in terms of 'responses' by pious Muslim women from the organized Turkish-Islamic milieu in the Netherlands to an increasingly polarizing public discourse. Jeanette Jouili, Christine $M$. Jacobsen and Nadia Fadil, on the other hand, put the voices of committed Muslim women more explicitly in the centre of their analyses.

Jouili's paper addresses the complex reflections on just social relations (including gender relations) and the good life brought forward by women active in the contemporary Islamic revival movements in Europe (particularly France and Germany). Much recent research conducted among these groups has focused on countering the idea that women's conscious turn to Islam is necessarily a reaffirmation of male domination, and on showing that this turn rather constitutes a possibility for agency and empowerment. However, certain 'traditionalist' positions defended by some women in revivalist Islamic movements seem to challenge such analyses. Taking this puzzlement as a point of departure, Jouili's contribution aims to think about the dilemmas involved in articulating a language for justice, dignity and self-realization, which competes with hegemonic notions of equality, individual rights and autonomy. 
Acknowledging this complexity in the fashioning of religious selves, Jacobsen's article investigates some of the challenges that anthropological research on Muslim religious subjectivities and practices poses to feminist theory. Grounding the discussion in ethnographic analysis of how young Muslim women in Norway speak about the 'self', Jacobsen argues that critically revisiting feminist notions of agency, autonomy and desire, is necessary in order to understand the kinds of self-realization that these women aspire to. However, the article argues against positing Muslim conceptions and techniques of the self as 'the other' of liberalsecular traditions. Rather, Jacobsen shows how configurations of personhood, ethics and self-realization drawn from Islamic and liberal-secular discursive formations inhabit not only the same cultural and historical space, but also shape individual subjectivities and modes of agency.

The particularities of different national contexts obviously play a role in how liberal politics are played out and how feminist traditions have been shaped. However, to us a more crucial question (than the inflationary one of convergences and/or divergences between Europe countries) seems to be whether perspectives such as those developed by Mahmood can be unproblematically applied to liberal-secular contexts in which Muslims are mainly present because of post-war migration processes. Both Jacobsen and Jouili problematize liberalsecular assumptions about freedom and self-realization while simultaneously bringing evidence of the power and effectiveness of these liberal-secular scripts for the formation of subjects. This point is made even more explicit in Fadil's contribution. She turns the growing scholarly investigation on Islamic veiling upside down by focusing on the issue of 'not veiling' among Muslim women as a bodily practice that merits the same close scrutiny as veiling. If and when attention is in rare cases accorded to 'not veiling', it is generally grasped as a product of secular governmentality. Drawing on narratives of secular and religious Muslims, Fadil pursues this perspective while shifting the analytical lens to practices of self-governance by examining to what extent the problematization of the hijab can be understood as an aesthetic or technique of the self, which reveal the embodied components of the problematization of the hijab. Juxtaposing such different subject positions reveals the complexity of the processes of subjectivation, which theorists from Foucault to Butler have written about so well on a theoretical level.

The productive power of secular liberal discourses and the 'powers of freedom' (Rose, 1999) also transpire from the 'Islam-critical' liberal feminist rhetoric adopted by public intellectuals such as Irshad Manji, Necla Kelek or Fadela Amara. These activists are cherished by political authorities as much as public opinion as the prototypes of 'liberated Muslim women', who favour a version of Islam that is retreated from the public stage to the privacy of personal belief (Fernando, 2009). Drawing on the French example, Sarah Dornhof's article highlights such processes of Muslim women's adoption of liberal-secular frames 
of seeing and being in the world. She enquires into the Ni Putes Ni Soumises (NPNS) movement and the traps resulting from their attempts to make visible Muslim women's suffering by Islamizing domestic violence and silencing the women's own voices. A critical reading of the ambivalent outcomes of political claims for visibility generates the question of how to access women's suffering beyond a representational regime in which the women themselves remain largely absent. Juxtaposing forms of visibility put forward by NPNS with (post-)migrant women's written witness accounts of violent experiences, Dornhof reflects on the conceptualization of suffering and agency that inform these modes of representation, suggesting that the written witness accounts may be read as 'dissenting words' in Rancière's sense.

The relationship between feminism and liberalism has always been an uneasy one. Yet, it seems that in the current climate, the identification of Europe and feminism as 'liberal' as opposed to an illiberal and traditional 'other' aligns feminism with liberalist agendas in a number of ways. As several of the articles in this volume show, feminism and liberal notions of individual rights, autonomy and gender justice have become intrinsic to the 'government' of European Muslims. The challenge for feminists or other scholars at this moment is thus perhaps not so much to address the question of whether feminism is reconcilable with Islam or whether multiculturalism is bad for women, but rather to dismantle the theoretical, analytical and ethnographic interface, with their particular configurations of power, of the complex and internally heterogeneous traditions that we identify as 'feminist' and 'Islamic'.

\section{Schirin Amir-Moazami, Christine M. Jacobsen and Maleiha Malik}

\section{authors' biographies}

Schirin Amir-Moazami holds a PhD from the department of Social and Political Sciences of the European University Institute in Florence. Since 2009, she has been assistant professor for Islam in Europe in the department of Islamic Studies at Freie Universität Berlin. She published a book on the headscarf controversies in France and Germany (Politisierte Religion. Der Kopftuchstreit in Deutschland und Frankreich, Bielefeld, transcript, 2007) and numerous articles related to questions of secular orders and Muslims in both countries. Her research interests include Islamic movements in Europe, Political Theory, Feminist Theory and the Sociology of Religion.

Christine M. Jacobsen is a social anthropologist trained in Bergen and Oslo and is currently a post-doctoral fellow at the Department of Social Anthropology and the research leader of IMER Bergen, Uni Rokkansenteret. Her work is in the field of International Migration and Ethnic Relations with a focus on Islam and Muslim 
minorities in Europe. In particular she has been concerned with changes that affect religious identities and practices among young people and women in a context of international migration, globalization and secular modernity. She has also been concerned with theorizing multiculturalism, in particular in relation to feminist theory. Jacobsen has published two books on Norwegian Muslims (the most recent being Islamic Traditions and Muslim Youth in Norway, Brill, 2011) as well as a number of national and international book chapters and journal articles.

Maleiha Malik is a professor in law. She studied law at the University of London and University of Oxford. She is a barrister and a member and fellow of the Honourable Society of Gray's Inn. Her research focuses on the theory and practice of discrimination law. She has written extensively on discrimination law, minority protection and feminist theory. She is the co-author of a leading text titled Discrimination Law: Theory and Practice, which was published in 2008. She also edited a special issue of Patterns of Prejudice on the topic of Anti-Muslim prejudice in the West, past and present, in 2009. Her current research focuses on the intersection between sexual and cultural equality, and it explores the adjustments that may need to be made to feminist theory to accommodate increasing cultural pluralism.

\section{references}

Abu-Lughod, L. (1986) Veiled Sentiments: Honor and Poetry in a Bedouin Society, Berkeley, CA: University of California Press.

Abu-Lughod, L. (2002) 'Do Muslim women really need saving? Anthropological reflections on cultural relativism and its others' American Anthropologist, Vol. 104, No. 3: 783-790.

Ahmed, L. (1992) Women and Gender in Islam: Historical Roots of a Modern Debate, New Haven, CT: Yale University Press.

Al-Hibri, A. (1999) 'Is western patriarchal feminism good for third world/minority women?' in Cohen, J., Howard, M., Okin, S.M. and Nussbaum, M.C. (1999) editors, Is Multiculturalism Bad for Women? Princeton, NJ: Princeton University Press.

Badran, M. (2007) Feminism beyond East and West: New Gender Talk and Practice in Global Islam, New Delhi: Global Media Publications.

Barlas, A. (2002) 'Believing women' in Islam: Unreading Patriarchal Interpretations of the Qur'an, Austin, TX: University of Texas Press.

Brown, W. (2006) Regulating Aversion: Tolerance in the Age of Identity and Empire, Princeton, NJ: Princeton University Press.

Deeb, L. (2006) An Enchanted Modern: Gender and Public Piety in Shi'i Lebanon, Princeton Studies in Muslim Politics, Princeton, NJ: Princeton University Press.

Fernando, M. (2009) 'Exceptional citizens: secular Muslim women and the politics of difference in France' Social Anthropology/Anthropologie Sociale, Vol. 17, No. 3: 379-392.

Göle, N. (1996) The Forbidden Modern: Civilization and Veiling, Ann Arbor, MI: University of Michigan Press.

Gressgård, R.E. and Jacobsen, C.M. (2003) 'Questions of gender in a multicultural society' NORA - Nordic Journal of Feminist and Gender Research, Vol. 11, No. 2: 69-77.

Hirschkind, C. and Mahmood, S. (2002) 'Feminism, the Taliban, and politics of counter-insurgency' Anthropological Quarterly, Vol. 75, No. 2: 339-354. 
Honig, B. (1999) 'My culture made me do it' in Cohen, J., Howard, M., Okin, S.M. and Nussbaum, M.C. (1999) editors, Is Multiculturalism Bad for Women? Princeton, NJ: Princeton University Press.

Mahmood, S. (2005) Politics of Piety: The Islamic Revival and the Feminist Subject, Princeton/ Oxford: Princeton University Press.

Mahmood, S. (2009) The politics of freedom: geopolitics, minority rights, and gender, http:// mrzine.monthlyreview.org/mahmood231109.html, accessed 16 February 2011.

Moghissi, H. (1999) Feminism and Islamic Fundamentalism: The Limits of Postmodern Analysis, London: Zed Books.

Okin, S.M. (1999) 'Is multiculturalism bad for women?' in Cohen, J., Howard, M., Okin, S.M. and Nussbaum, M.C. (1999) editors, Is Multiculturalism Bad for Women? Princeton, NJ: Princeton University Press.

Phillips, A. (2007) Multiculturalism without Culture, Princeton, NJ: Princeton University Press.

Rose, N. (1999) Powers of Freedom: Reframing Political Thought, Cambridge, UK: Cambridge University Press.

Wadud, A. (2006) Inside the Gender Jihad: Women's Reform in Islam, Islam in the Twenty-First Century, Oxford, UK: Oneworld Publications.

doi: $10.1057 /$ fr. 2011.9 